\title{
ISLAMIC BANKING AND FINANCE TODAY Issues and Implications
}

\author{
Lateef Kayode Adeyemo and Kamil Koyejo Oloso*
}

\begin{abstract}
Far from being a curiosity, Islamic banking and finance products have come of age as a force to be reckoned with in the international financial market, breaking new ground and making giant strides by the day. This growth and geographical expansion has given rise to several challenges which can no longer be ignored but must be addressed by academics and scholars, professionals and practitioners in the industry, technocrats in government circles, standards boards and allied organisations, and Shariah experts and other jurist consultants. Some of these challenges pose a significant threat to the further growth and development of the industry, if left unaddressed. This paper attempts to look into such issues and to proffer solutions to them in order to ensure the even and healthy growth and development of the industry.
\end{abstract}

\section{Introduction}

Islamic Banking and Finance today is making giant strides in terms of products and services and is spreading to all parts of the world. The success story has not come without challenges. These challenges are diverse and multidimensional. The earlier they are addressed, the better for the industry, as this would enable the industry to further move ahead. The challenges range from the Shariah compliance of certain products and services rendered by some Islamic banks to certain risks that are peculiar to the system. They also include the validity or Islamicity of the industry itself, as some scholars are of the opinion that there is no such thing as Islamic banking. The challenges relating to cross-border practices and litigation of cases arising from the practice of IBF, training and retraining of personnel, regulations and codes of conduct are wide ranging and considerable. Islamic Banking and Finance and the war against terrorism, the lack of an enabling environment, the problem of riba, controversy among scholars and advisory boards, dual legal systems within particular jurisdictions, confusion in the adjudication of matters relating to IBF, Islamophobia, and the role of the mass media are just some of the challenges that urgently need attention.

Although in many areas Islamic Banking and Finance has come of age, yet some scholars have raised issues about its validity, as far as the Shariah is concerned. To them, it is no more than a clever way of circumventing the law otherwise known as hilah in Islamic legal parlance. Consider for example the fatwa issued in 1989 by the late Sheikh al-Azhar, Muhammad Sayyid Ali Tantawi, in which he ruled that interest from conventional deposits is permissible. This is contrary to the judgment pronounced by Sheikh Taqi Uthmani as well as the fatwa issued 
by Sheikh Annas al-Zarqa. The controversy on the validity of tawarruq is not a good omen for the further development of the industry. Muhammad Nejatullah Siddiq (2006) ${ }^{1}$ observes that Sheikh Nizam Yaqubi declared organised tawarruq as valid even though it brings more harm than good, and the recent judgment on sukuk by Sheikh Taqi Uthmani declared that sukuk is not Shariah compliant. ${ }^{2}$ When Sheik al-Azhar, Muhammad Sayyid Ali Tantawi, in 1989 concluded that the interest from conventional deposits is permissible, that conclusion was to the utter chagrin of the Muslims across the globe.

For example, while Al Bai Bithaman Ajil (BBA) or "deferred payment sale" is accepted as a valid mode of financing in Malaysia and certain other countries, it, or at least some aspects of it, is considered invalid in the Middle East. This is another issue through which interest is feared to have crept in and is the reason why some states or countries do not see it as a valid product or service. Of course, the idea of bay al-inah, which is applied in BBA financing, is actually a legal device to get loans and is invalid according to the Maliki and Hanbali schools and under the Shafi'i school of thought is considered very weak. ${ }^{3}$ One is therefore skeptical of its validity. This is perhaps one of the reasons why some scholars have passed a general and blanket fatwa that Islamic Banking is un-Islamic.

The hindrances created by the secular nature of certain states, particularly those of Muslim nations, have limited the practice of Islamic Banking and Finance. The duty of an Islamic state is to uphold justice and the welfare of the citizens including equitably distributing wealth. ${ }^{4}$ This can only attained when and where necessary facilities or machineries of the state have been tailored towards this lofty goal.

There are yet some states where common law is used to adjudicate on matters relating to Islamic Finance. This situation often leads to problems or disparities in the system. There are also instances where although Islamic law is adopted along with common law, Islamic law has been subsumed under conventional law and is thus unable to function properly. Such situations have not allowed proper adjudication of cases or issues arising from Islamic financial services and products.

The absence of a codified version of Islamic commercial law in many jurisdictions' legal and constitutional frameworks equally constitutes a serious challenge to the growth and development of Islamic financial services and products. The misconceptions about Shariah and its objectives when Islamic contracts are prepared by conventional lawyers who have no proper training in Islamic law is a hindrance to the growth of IBF. ${ }^{5}$

Some of these challenges are considered in the survey that follows:

Islamic Finance broadly refers to financial activities that are guided by the teachings of Shariah (the Islamic law), which strictly prohibits the payment and 
receipt of interest (Iqbal, 1997:4). ${ }^{6}$ However, as Iqbal says, "describing Islamic financial system simply as 'interest free' does not reflect a true holistic picture of the System." Islam in general and Islamic Finance in particular strive for the preservation of property rights, shoring up ethical standards, sharing of risk, and promoting social justice. He posits further that "not only must investment activities be in line with the ethical principles of the Shariah, they should also take into consideration public interests (masalih)." In view of the foregoing, the present practice seems to have been over-burdened with looking at products and services from the perspective of compliance with Shariah rather than being based upon or grounded in Shariah: the "first best" practices envisaged or aimed at by the pioneers of Islamic Banking and Finance. We will return to this theme later.

\section{Validity of Islamic Banking and Finance}

On 29 August 2008, a fatwa was issued by a group of jurists declaring Islamic Banking and Finance as inconsistent with Shariah principles and therefore un-Islamic. M. T. Mansori $(2010: 7,9)^{7}$ argues that the main contentions were based on the concept of islah. It was argued that Murabaha and Ijarah are legal stratagems (hilah) and not real alternatives to interest. According to Muneeza et al $(2010)^{8}$, hilah simply means a legal device. The Arabic term hiyal is the plural form of hilah, which means a device, expedient, artifice, stratagem or way of evading or affecting an object. So, to classical Arabic lexicographers like Ibn Manzur (1999), ${ }^{9}$ the original meaning of the word hilah and its other derivatives like hayl, tahayyul, ihtiyal and so forth connote ingenuity, skill in management of affairs, shrewdness, ruggedness of intellect and cleverness. Imams Malik and Ahmad disapproved of the use of hilah in any shape or form.

However, if the findings and conclusions reached by Fage $(1978: 157)^{10}$ are true, the current controversy over the validity or Islamicity of Islamic Banking and Finance is unfounded, unwarranted and uncalled for. He states: "Beyond the immediate circle of the court, the keys to advancement and wealth were no longer military valour, but success in business or banking, ${ }^{11}$ law or scholarship." 12 However, it is good to examine whether the current practice satisfies Islamic intents and objectives, that is, the maqasid Shariah, the higher objectives of the Islamic law.

The question whether Islamic Banking and Finance has an historical presence or is just an imitation of conventional banking has been discussed by scholars who concluded that certain terms of modern banking and finance originated in Arabic, and were either Anglicised or Gallicised as the case may be, as pointed out by Doi (1980:398-402).$^{13}$ In his work, Shariah - the Islamic Law, Doi suggested that banking has been part of Islam from the earliest times and it is therefore not alien to Islam and the Muslims, as claimed by some scholars. For example, Mohatra, 
which means risk, was taken from the original Arabic Mukhatarah. The same thing applies to a bill of exchange, which derives its origin from Suftajah. Doi concludes that Muslims were the first to lay down the true foundations of proper trade and even banking in modern civilisation, stressing that present-day banking terminology is replete with Arabic words and expressions. The very word cheque is originally Arabic, from sakk (pl. sukuk); traffic and trafficking originate from the Arabic tafriq. He further suggests that buy derives from the Arabic bai', a word Anglicised from the original Arabic source. Acheter is ishtara; tariff is ta'rifah, both of which were, according to him, Gallicised by the French.

According to Al-Yaqubi (d. $897 \mathrm{CE}$ ), an early Muslim historian, 'Umar Ibn alKhatab (634-644 CE) was the first to draw cheques and to put his seal underneath and sign them. A similar statement was made by Al-Jahashiyari (d. 942 CE) in respect to Harun Ar-Rashid,: that "Al-Fadhl asked him [Ar-Rashid] to draw a cheque in his own hand with regards to this sum of money". Ibn Miskawaih (d. 1030) in his Tajarib al-Umam also mentioned that the wages and salaries of the army were paid via cheques and that one of the major charges made against Muhammad bin Dawud was that he paid the army in cash instead of cheques. So, the custom of using cheques became a common practice among the general populace. Thus, centres of money exchange were established by the Muslim merchants in different parts of the Muslim world and beyond. Muslim states and dynasties all over the world embraced this well-established banking and finance system, scrupulously avoiding riba in all shapes and forms. If as a result of Western ascendancy the world has forgotten this aspect of Islamic history on banking and finance, then it is time for this to be changed. Capitalist banking and finance has been struck by major crises. The combined effects of the Great Depression (1930s) and the recent economic meltdown (2008 to date) have perhaps provided an opportunity for Muslims to revisit Islamic economics, banking and finance, with a view to the possible contribution they could make today.

\section{Cross Border Practices and Litigations}

According to Adeyemo and Mobolaji (2010:5), ${ }^{14}$ cross-border practices mean the practice of a trade, profession, or art beyond the shore or border of a nation. Such practices generate an international outlook, consistent with the practice of Islamic Banking and Finance across borders of two or more nations or countries (called jurisdictions in legal parlance). We agree that unless necessary rules and regulations, policies or codes of conduct or ethics are properly formulated and seriously enforced, such practices may be problematic, given differences in laws, jurisdictions, cultures and the prevailing circumstances in each of the jurisdictions concerned. 
Litigation for Adeyemo and Mobolaji (2010:5) is the process of making or defending a claim in a court of law, that is, the procedure or process for seeking redress in certain issues of contention or resolving them in a court of law. Thus, in this case it refers to settling disputes or misunderstandings arising from crossborder (global) practices of Islamic Banking and Finance. There should be deliberate, conscious and concerted efforts by the stakeholders in the industry to promulgate necessary laws and formulate suitable policies within the purview or ambits of Shariah, in order to ensure the better functioning of the industry. Otherwise, there will be a continual conflict of laws and jurisdictions, as it will be difficult to determine which of the jurisdictions or laws should be used to adjudicate in a matter. However, in the interim, particularly in a situation whereby such policies and laws are non-existent or yet to be formulated, Alternative Dispute Resolution (ADR) may be resorted to if the parties to the conflict or misunderstanding so agree. This is fast and economical and facilitates an amicable resolution because the matter is based on a mutual diplomatic process. ADR is amenable to the Islamic approach and resembles the Islamic concept of tahkim.

Muhammad Zakhiri Bn Muhammad Nor (2010:2) $)^{15}$ observes that fatawa, Shariah resolutions and civil law often tend to overlap and are not properly integrated; the proper integration or co-ordination of all regulations could ensure the healthy growth and proper functioning of the industry. Given the geographical spread of the industry, this is worth considering and would give a positive role to the higher objectives of Shariah, the maqasid al-Shariah. This would also facilitate a degree of uniformity in the global practice of Islamic Banking and Finance.

\section{Training and Re-training of Personnel}

With Islamic banking and financial products becoming more popular not only among the Muslim nations but within non-Muslim states, there is a resultant dearth of competent personnel, including Shariah scholars, to serve on the Shariah advisory boards of banks and the Shariah Advisory Councils of several central banks. Universities and colleges need to establish relevant programmes at both the undergraduate and graduate levels in order to overcome this challenge. More than simply one-off training for those going into the industry, there should also be in-service (refresher) training opportunities for those who are already practicing, and there is a need to organise conferences, symposia, seminars and workshops to address new issues that are arising, given the dynamism of the industry. This would provide avenues for practitioners, researchers and university and college dons to interact, exchange ideas and provide solutions to problems as they arise. Scholarships should be awarded to promising students, particularly at the graduate level, for research grants in certain areas. 
More Shariah scholars who are well grounded in Mu'amalat are needed, as Mansoor observes $(2010: 3)^{16}$, in order to ensure the validity of new products and sustain public confidence. Adeyemo et al (2010:8) have noted that 'Umar Ibn alKhatab said: "No selling (is permitted for anyone) in our market save (for those who) comprehend religion." They see the above hadith, credited to "Umar alKhattab, who was more than just one of the leading companions of the Prophet but one of the Rightly-Guided Caliphs, as allowing the question of whether modern training in IBF is adequate, particularly of those who are not Muslims. For the knowledge intended by Caliph 'Umar in this report is one that leads to practices born of conviction as the direct result of acquired knowledge. They believe that the Islamic epistemology and philosophy of education and learning is Learn to know, know to practice, practice to become; you are what you practice. One who has learnt Islam is therefore required to practice it; by so doing he becomes a practicing Muslim; for knowledge is useless when left unused by the one who acquires it. Islam is a practical religion; if one acts in contradiction to what he advocates, he lacks credibility and courts rejection by others.

The present situation whereby a person may serve on as many as seventy boards across the globe is unhealthy and beyond the limits of sound advice: issues cannot be properly attended to before decisions are reached. The observation made by Muhammad Razif Abd. Kadir (2009) ${ }^{17}$ is worth repeating here: "For Islamic finance to move forward, we have to review how we practice Islamic finance ... Currently, Islamic finance assessment is compliance-based ...; compliance is not the problem, but we must ask ourselves, is that enough?" There is a need for a paradigm shift, that is, a shift to basing the assessment of the system on the spirit of the Shariah rather than on compliance with the letter of Shariah, favouring a Shariah-based approach as distinct from a more mechanical Shariah compliance, as has been in vogue for quite a while.

Iqbal A. Khan $(2008)^{18}$ has elaborated on this recommendation:

The challenge we now face is to enable a transition from Shariah-compliant to a Shariah-based approach. A Shariah-based approach represents holding to the spirit as well as the letter of Shariah, and look to finance genuine economic activity with a more authentic model. It represents an attempt to capture the essence of Islamic economic ethics, which, to me, is built on fairness, risk sharing, and an investment orientation. No matter how successful Islamic banking is today, we must confess that a contemporary model of Islamic banking is not exactly the "first best" that we were hoping for ... So far, Islamic banking is the product of financial engineers trying to design structures that can deliver the same economic outcome of conventional banking products while meeting requirement of Shariah-compliance. The end result is the mere modification of an already existing system to meet constraints ... [This practice] only considers "legalistic" limitations by observing the constraint of haram. 
The paradigm shift from Shariah-compliance assessment to Shariah-based should be incorporated into the curricula or syllabi of personnel training, to improve on the present system's approach, which is akin to hilah. Perhaps this is why some scholars are contesting the Islamic validity of current practice.

\section{Regulations and Code of Conduct}

There is an urgent need for harmonised rules and regulations. Fatawa are persuasive but not binding before a court of law and are valid only when duly gazetted and codified. This will ensure uniformity and facilitate easy access to legal facilities in the event of misunderstandings arising from Islamic Banking and Finance, particularly in regard to diverse global practices. Indeed, regulatory and Shariah considerations apart, there are compelling reasons for good corporate governance of Islamic financial institutions. Mansoor (2010:7) includes as incentives, implementation of effective corporate governance strategies: the ability to reduce the cost of capital, enhancing operational efficiency, reduction of risk and fostering resilience to external shocks.

For Mansoor, an effective corporate governance framework must have key strategies with performance measurement methods of defining responsibilities and clearly visualised accountability, appropriate internal controls and monitoring mechanisms. This framework ensures compliance with rules and regulations, promotes a culture of compliance and rewards those who value good governance in Islamic Finance Institutions (IFI). It would protect employees who have been steadfastly compliant with regard to corporate governance. "If the Islamic Finance Industry does continue to grow at the pace it has sustained in recent years, there is likely to be tremendous challenges alongside the successes of the industry. From all indications and given the market potentials, there is no doubt this industry will grow tremendously unless factors of a very serious nature unexpectedly emerge to hamper its growth."

The World Bank publication Risk Analysis for Islamic Banks points out: "The activities of Islamic banks and banking may affect the welfare of more than 20 percent of the world population mostly concentrated in developing countries, and their corporate governance arrangements matters for economic development." According to Iqbal et al (1999), ${ }^{19}$ corporate governance in Islamic Finance entails implementation of a rule-based incentive system that preserves social justice and order among all members of society. There can be no doubt that there is an urgent need to come up with codes of conduct and a Shariah-based, not merely Shariahcompliant, corporate governance system suitable for IBF. From the World Bank Risk Analysis for Islamic Banks comes the observation: "Islamic banks emphasise services to multiple stakeholders. Governance processes and structures inside 
and outside the firm are needed to protect the ethical and pecuniary interests of shareholders and stakeholders."

Hence the Shariah validity requirement must exist side by side with effective corporate governance in the industry. Directors, for their part, must ensure that the directives of the Shariah Board are being complied with. Hence there is a need for proper monitoring mechanisms, the sine qua non for the realisation of these objectives. The management must also be vigilant at the post- Shariah Board approval stage. For it has been observed that a product which may seem compliant when examined in isolation by the Shariah Board may pick up deviant characteristics at the stage of implementation, as these involve human participation, and certain product features may have been missed by oversight at the approval stage. Hence the Shariah Board's attention may be needed at the product implementation stage as well. If products are Shariah-based rather than merely compliant, we would be spared many of the problems and challenges currently faced. There should be a provision for regulating the extent of disagreement and controversies so that they do not transcend the limit set by Islam, which is on the whole aimed at islah. Hence, the lawmakers, or rather the standard-setters, must be guided by certain rules and regulations to ensure the general acceptability of the standard set by them.

\section{Islamic Banking and Finance and the War against Terrorism}

Alex Anderson and Mahbub Bhuiyan (2010:427 ${ }^{20}$ have observed that with the act of terror of 11 September 2001, a black mark was left on Islam and the Muslims, and this has changed not only the lives of Muslims around the world but also the security landscape across the globe. Islamic finance was blemished and blamed for an international flow of funding to terrorists. This connection has yet to be proven. Nevertheless, international terrorism has emerged as the most immediate threat to not only global security but the future of the world in its entirety and of Muslims in particular. Crimm (2008) ${ }^{21}$ has noted that "Islam stresses the importance of Zakat and Sadaqah to Muslims as philanthropy and charity. Islam places a high value on compassion, wealth redistributions, social justice, and supporting and enhancing fellow humans; both philanthropy and charity [therefore] play crucial roles for Muslims and their societies". Muslims, particularly those who live as minorities in Europe, America and elsewhere across the globe, may feel disenfranchised, isolated and alienated from their fellow Muslims and the rest of the world as an outcome of the West's waging war against terrorism and the quest to flush out those funding terrorism. This situation has subjected Islamic banks and banking to certain risks and greater scrutiny, and has therefore led to certain constraints in their operations. 


\section{Creating an Enabling Environment}

Countries operating IBF today do so either as a full-fledged Islamic Banking and Finance system or as a window under the existing conventional system. But in any case IBF operates under laws and environments that are if not totally alien to it then are at least at times unfriendly, thereby exposing it to certain peculiar risks. Sometimes cases emanating from Islamic banking and financial services and products are referred to civil court for adjudications. This is particularly problematic in a situation in which those hearing the case have little or no training in Islamic commercial law or Muamalat. There are cases in which dual legal systems are practiced in certain states, yet under such circumstances Shariah is typically applicable only in principle but subordinate to common law in practice. This situation has severely constrained some of the Islamic banks; hence there is a need to review existing law to bring about some comparative advantage, in order to compete favourably with the existing conventional system. The United Kingdom has provided a cue in this direction which is worth considering.

\section{The Problem of Riba}

Scholars have raised concerns about the validity of certain products which are riba or interest based. The avoidance of interest in an Islamic economy is of paramount importance, although Islamic Banking and Finance entails more than simply being interest-free. It is in any case critical to ensure that all products and services rendered by Islamic banks and similar financial outfits are devoid of interest, regardless of what form it may take, whether Bai'al-Inah, tawwaruq or commodity murabahah, sales of debt derivatives and so forth, to ensure the uniformity and vitality of the industry. Beyond what is clearly lawful or clearly prohibited, there is a need to spotlight ambiguous or gray areas and to stay clear of doubt and unlawful indulgence; for whosoever falls into ambiguity strays towards the haram.

\section{Controversies among Shariah Scholars and the Problem of a Dual Legal System}

There is continuing controversy over whether gold or silver should be the basic unit of value. Throughout the long history of Islam and in Islamic economics, money has been considered to be a means of exchange and not a commodity. The question of whether money should necessarily consist of gold or silver is perhaps problematic. Caution should be exercised in proffering solutions that may create greater problems, or a solution that is more pernicious than what needs to be solved. Most of the issues should now perhaps be addressed by scholars of different legal schools, so that they could deliberate on issues and 
reach consensus on the best advisable course, taking into consideration the higher objectives of Shariah.

In Malaysia, for example, Islamic banking and financial matters fall within the jurisdiction of the civil court though they are fiqh mua'malaat matters. ${ }^{22}$ Scholars have offered solutions to this problem; however, it has not worked out as expected. For instance, Muhammad Zakhiri advocates integration of al-fatwa, al-imaamah and al-qadaa. He stresses that there should not be conflict between them and therefore there is a need to work together, harmonise and codify these ordinances. Unfortunately, as he has observed, we can see that Shariah has been used as an escape route by the debtor not to pay the creditor, as in the case of the Investment Dar Company KSCC v Blom Development Bank SAL, when a certain product had been declared as invalid by the court even though the Shariah Board had already issued a resolution/fatwa and approved that the product is Shariah compliant, using the argument that Islamic banking businesses are not fully Islamic as they are dependent on their conventional counterparts. Disparities of this kind will not only put the Islamic finance industry in a state of uncertainty and cause confusion among the general public but more importantly put the industry into disrepute, if it is not able to realise its set objectives, he observed.

Salim Ali Al-Ali \& Younes Soualhi (2010)" assert, "Whereas, from a regulatory point of view, Accounting and Auditing Organizations for Islamic Financial Institutions (AAOIFI) resolved that surplus in takaful fund belongs to takaful participants only, hence, takaful operators are not entitled to receive any part of the surplus. However, contrary to this, Bank Negara Malaysia (BNM) ruled that surplus should be shared between takaful participants and operators."

Anne Sophie Gintzburger (2010) ${ }^{24}$ observes that the variation in opinions on contracts may be attributed to a diversity of backgrounds, to schools of jurisprudence, the college or the university where training was acquired, as well as to the environment in which the members of the Shariah board functions. In theory, Islamic Finance relies on equity participation - the system is still developing currently, it is yet to develop real equity finance globally. There is an urgent need for dialogue between Malaysian Islamic financial experts and those of Gulf Co-operation Council in order to exchange ideas, cross fertilise them and avoid unnecessary controversy. This will bring about a convergence of opinions rather than divergence and conflict. In determining the validity of a product or service, the Qur'an, the Sunnah, Ijma', etc. should in this order be given priority, and as Adeyemo and Mobolaji note, any ambiguity should be avoided.

Edib Smolo and Elmin Habibovic $(2010)^{25}$ point out that "being a niche industry, Islamic Finance is faced with a long list of tasks ahead that need to be conquered before it may be elevated to the next level." Singh $(2009)^{26}$ states 
that Islamic Finance industry is in its adolescence when it comes to issues like transparency, accounting and ratings, with very different standards being used. Robinson $(2005)^{27}$ adds that there is therefore an urgent need for standardisation to ensure uniformity, one that is aimed at effecting transparency, credibility, integrity and accountability in the industry.

The name Islamic Finance may lead someone to believe that it is only for the Muslim countries with majority Muslim populations. However, it is being argued that the majority of Islamic finance customers are actually non-Muslims. Today, Islamic finance attracts both Muslim and non-Muslim market participants (Monger \& Rawashdeh, 2008). ${ }^{28}$ In fact, the United Kingdom is leading the Western, non-Muslim countries in developing Islamic finance services. With $\$ 19 \mathrm{bn}$ of reported assets as of the end of 2008, the United Kingdom is ranked eighth and is considered Europe's premier place for Islamic Finance. This was attained by the joint efforts of the UK government, the Bank of England and the Financial Services Authority (FAS), who identified the main barriers for the introduction of Islamic Finance and took proactive steps in creating a level playing field for Islamic financial services to thrive. Other countries are joining the bandwagon. For example, Singapore, Hong Kong, France, Germany, Luxemburg and Ireland, to mention a few, all either amended their laws or are on the track to do so in order to facilitate the development of the Islamic financial industry. Other countries, including Muslim and non-Muslim states, should emulate the United Kingdom by providing a level field for Islamic Finance to thrive and compete favourably with the existing conventional system.

Islamic Finance is faced with a number of challenges calling for the prompt attention of the Muslim scholars, most particularly those who are specialists in Fiqh Mu'amalat. The industry will move ahead if the right responses are given at the right time. Karuvelil (2000:155) $)^{29}$ thus states, "The industry [Islamic Finance] faces considerable challenges; its response to them will determine whether it will become a significant alternative to the conventional system in global financial markets." There is therefore a pressing need to make provision for an efficient legal framework, qualified personnel, standards, procedures and codes of conduct, and to find the will power on the part of governments to support the industry in order to safeguard it from increased risks to which it is exposed $\left(\right.$ Khorshid, 2009) ${ }^{30}$. Divergence of opinions among Muslim jurists regarding the validity or non-validity of certain products needs to be restrained for the good health and even growth of the industry. Hence, opinions need to be harmonised, standardised and codified (Shanmugam \& Zahari, 2009) ${ }^{31}$. The use of different terms and terminologies among scholars, banks and other Islamic financial outfits should be moderated too and adequately regulated. There is a need therefore for integration and harmonisation in order to ensure uniformity and to guard against 
confusion, particularly among the general public, most of whom are not, at least as of now, conversant with them.

\section{Conclusion}

Although Islamic Banking and Finance is doing very well and making giant strides by the day, the growth has not come without challenges. If these challenges are met appropriately at the right time, further growth of the industry can be expected. However, if they are neglected or wrong and unsuitable solutions are proffered, that may have an overall devastating effect on the industry. Voices have been raised questioning the validity, or Islamicity, of certain products. Experts are now saying that rather than "Shariah-compliant" (which invariably signifies adopting/adapting the existing products of the conventional system), we should look inwardly into Shariah-based products. The controversy between the various Shariah boards and councils should be laid to rest and an attempt should be made to unify and codify their resolutions and fatawa. The need for the training and retraining of professionals and experts in this field cannot be over-emphasised. Such training should be focused on Shariah-based products and services so as to move beyond Shariah compliance, which is second best, and move ahead to Shariah-based products and services: a positive approach to Islamic finance as indeed "the very first best" is intended by our predecessors. Research needs to be encouraged in this field of studies. The following policy recommendations are for consideration by the appropriate authorities.

\section{Policy Recommendations}

- Governments or their agencies in each of the jurisdictions where IBF operates should, in conjunction with standard boards, come up with codes of conduct not only for the practitioners but equally for Shariah advisors and advisory boards;

- More universities and colleges should introduce relevant programmes to cater for the growing need for trained personnel in the industry;

- In order to ensure the effective global operations of IBF, all regulations, laws, and fatawa should be properly codified and harmonised and made easily accessible;

- There should be regular conferences, symposia and seminars where scholars, university and college dons as well as researchers exchange ideas, cross fertilise them and proffer solutions to challenges as they arise, to further develop the industry;

- Research grants, scholarships and endowments should be offered to motivate scholars and researchers to engage in further in-depth enquiry; 
- Scholars who make ground-breaking discoveries or contributions should be recognised through suitable awards and prizes of varying degrees to motivate innovative scholarship;

- There should be a paradigm shift from mere Shariah compliance to laws based upon the foundations of Shariah, a shift which should be reflected equally in syllabi for training personnel and in training materials;

- Civil courts that have no experts in Fiqh Mu'amalat (Islamic Commercial Law) should not be allowed to adjudicate on matters relating to IBF without the presence of qualified Shariah experts;

- There is a need to harmonise major terms and technical expressions used in IBF in order to avoid confusion.

\section{Notes}

* Lateef Kayode Adeyemo is a Lecturer in the Department of Philosophy and Religions, Faculty of Arts, University of Benin, Benin City, Nigeria. This article is a revised version of a paper presented at Langkawi Islamic Finance and Economics International Conference (LIFE 2), organised by Insaniah University College, Islamic Research and Training Institute (IRTI) and Islamic Development Bank (IDB) on the theme: Sustainable Development in Muslim Countries: Economic Policies in the Light of Maqasid al-Shariah, held 13-15 December 2010.

1. Muhammad Nejatullah Siddiqui. "Economics and the Role of Shariah Experts", delivered at the Seminar on Islamic Banking and Finance: Islamic Banking and Finance After 40 Years, 30 August 2006. Kuala Lumpur, Malaysia.

2. Usmani Muhammad Taqi. Principle of Shariah Governing Islamic Investment Funds, Writings on Islamic Modes of Finance. Failaka International, access at www.failaka.com/customer/resources.jsp.

3. Quoted in Salim Ali Al-Ali and Younes Soualhi. "Sharing of Underwriting Surplus in Takaful Operation: Practical Perspectives", in Proceeding of International Conference on Islamic Banking and Finance: Cross Border Practices and Litigations 2010, pp. 20-32.

4. Adeyemo, L.K. and Mobolaji, H.I. "Islamic Banking Practices and the Need for Ethical Concerns", Islam and Civilisational Renewal, April 2012, Volume 3, No. 3, pp. 506-526.

5. Ibid.

6. Iqbal, Z. "Islamic Financial System", Finance and Development, June, 1997, 34, 42-45.

7. Mansori, M.T. "Shariah Legitimacy of Islamic Banking", in Proceeding of International Conference on Islamic Banking and Finance: Cross Border Practices and Litigations 2010, pp. 7-9.

8. Aisath Muneeza, Nik Nurul Atiqah Nik Yusof, et al. 'Hilah in the Banking Instruments in Malaysia with Reference to the Banking Practices in Other Jurisdictions: Is there a Need to Standardize Islamic Banking Instruments Used in All the Jurisdictions?' in Proceeding of International Conference on Islamic Banking and Finance: Cross Border Practices and Litigations 2010.

9. Jammaluddin Muhammad Ibn Makram Ibn Manzur. Lisanu Al-Arab, (Beirut: Dar Sadir \& Dar Beirut lil-Tiba'a wa al-Nashr, 1999), Vol. 3, p. 339.

10. Fage, J.D. A History of Africa, (London: Hutchinson \& Co Ltd. 1978), p. 157. Emphasis ours based on its relevance to the issues under studym

11. Doi, Abdur-Rahman I. Shariah-The Islamic Law, (London: Taha Publishers, 1980), pp. 398-402.

12. Nizam Yaqubi. 'Reuter's 'Organised Tawarruq is Valid Under Shariah', Kuala Lumpur: Malaysia Reserve (2009) and Muhammad Nejatullah Siddiqui. Economics of Tawarruq: How its Mafasid Overwhelm its Masalih in Tawarruq: A Methodological Issue in Shariah Compliant Finance (2007).

13. Doi, A.R.I., pp. 345-560.

14. Adeyemo, L.K. \& Mobolaji, H.I. Islamic Banking and Finance Today: Professional Ethics and Cross 
Border Practice and Litigations in Proceedings of International Conference on Islamic Banking and Finance: Cross Border Practices and Litigations, (Kuala Lumpur 2010).

15. Mawardi (2003), Al-Ahkam As-Sultaniyyah, Al-Qairah: Dar Al-Nahdah Al-Arabiyyah; see also Muhammad Zakhiri (2005:5).

16. Mansoor, op. cit.

17. Muhammad Razif Abd Kadir. ISRA Bulletin (April, 2009), Vol. 2.

18. Iqbal A. Khan. "Perspective on Tawarruq", a Paper Presented at the Workshop on Tawarruq: A Methodological Issue in Shariah Compliance Finance, (Kuala Lumpur, Feb.1, 2008).

19. Iqbal \& Abbas Mirakhor. "Progress and Challenges of Islamic Banking", Thunderbird International Business Review, 41 (4-5 July-October, 1999), 381-405.

20. Alex Anderson \& Mahbub Bhuiya. "Financing Terrorist: Does Islamic Financing Has a Role?", Proceedings of International Islamic Finance Conference, IIFC, LABAN 2010:7.

21. Crimm, N.J. "The Moral Hazard of Anti-Terrorism Financing Measures: A Potential to Compromise Civil Societies and National Interests" in Legal Studies Research Series Paper No. 08-0139, October, 2008.

22. Zainal Azam Rahman. "The Application of Islamic Law of Contract: Issues and Challenges in Islamic Finance", INCEIF, Kuala Lumpur, (2009), p. 5; see also Zainal Azam Rahman, Islamic Finance in Malaysia (Legal and Shariah Framework), accessible at: wems2.lofsa.gov.my/.../shariah0/020legal0/ 020of0/020islamic0/020finance0/020 ...; Also see Wan Azhar. Whither Jurisdictional Conflict in The Star, Kuala Lumpur (2007).

23. Salim Ali Al-Ali and Younes Soualhi (2010), "Sharing of Underwriting Surplus in Takaful Operation: Practical Perspectives" in Proceedings of International Conference on Islamic Banking and Finance: Cross Border Practices and Litigations (Kuala Lumpur: 2010). Also see Mahmoud A. El-Gamal. Islamic Finance Law, Economics, and Practice, (London: Cambridge University Press, 2006). Also see Baker, M.O. 'AAOIFI Pronouncement on Sukuk: History, Implications and the Way Forward from Shariah Perspective', in the Proceeding of Global Update on Sukuk: Post AAOIFI Pronouncement, Held at Hotel Nikko, Kuala Lumpur, Malaysia, (2008). p. 5.

24. Anne Sophie Gintzburger. 'An Analysis of Global Trends and Regional Pockets in the Application of Islamic Financial Contracts in Malaysia and the Gulf Cooperation Council', in the Proceedings of International Conference on Islamic Banking and Finance: Cross Border Practices and Litigations, Kuala Lumpur (2010), p. 3.

25. Edib Smolo and Elmin Habibovic. 'Islamic Banking and Finance Beyond Borders: Issues of Standardization', in the Proceedings of International Conference on Islamic Banking and Finance: Cross Border Practices and Litigations, Kuala Lumpur, (2010).

26. Singh H. 'World Desperately Looking for Sustainable Financial System', The Malaysian Reserve (2009, April 30), p. 14.

27. Robinson K. (2007, Nov. 5), 'Islamic Finance is Seeing Spectacular Growth', New York Times retrieved from: http//www.nytimes.com/2007/11/05/worldbusiness/05ihtbankc0106.3.8193171.html.

28. Monger, R. and Rawashdeh, M. "Islamic Finance Enters the Mainstream", Management Accounting Quarterly, (2008), 9 (3), 1-6.

29. Karuveli, K.Z. "Islamic Finance: Sustaining Success of Islamic Finance: Local Challenges, Global Opportunities", Proceedings of the Third Harvard University Forum on Islamic Finance Cambridge, Massachussetts: Centre for Middle Eastern Studies, Harvard University, (2000), pp. 155-158.

30. Khurshid A. 'Time to Clarify Opaque System', Islamic Banking and Finance, (2009), 6 (5), 11-12.

31. Shanmugam, B. and Zahari, Z.R. Primer on Islamic Finance, The Research Foundation of CFA Institute, (2009). 